

\title{
Distant swells and their impacts on atolls and tropical coastlines. The example of submersions produced by lagoon water filling and flushing currents in French Polynesia during 1996 and 2011 mega swells
}

\author{
Rémy Canavesio
}

\section{To cite this version:}

Rémy Canavesio. Distant swells and their impacts on atolls and tropical coastlines. The example of submersions produced by lagoon water filling and flushing currents in French Polynesia during 1996 and 2011 mega swells. Global and Planetary Change, 2019, 177, pp.116-126. hal-02551447

\author{
HAL Id: hal-02551447 \\ https://hal.science/hal-02551447
}

Submitted on 22 Oct 2021

HAL is a multi-disciplinary open access archive for the deposit and dissemination of scientific research documents, whether they are published or not. The documents may come from teaching and research institutions in France or abroad, or from public or private research centers.
L'archive ouverte pluridisciplinaire HAL, est destinée au dépôt et à la diffusion de documents scientifiques de niveau recherche, publiés ou non, émanant des établissements d'enseignement et de recherche français ou étrangers, des laboratoires publics ou privés.

\section{(ㄷ)(1) $\$$}

Distributed under a Creative Commons Attribution - NonCommerciall 4.0 International 
Distant swells and their impacts on atolls and tropical coastlines. The example of submersions produced by lagoon water filling and flushing currents in French Polynesia during 1996 and 2011 mega swells.

Remy Canavesio ${ }^{1,2,3, *}$ remycanavesio@ hotmail.fr

${ }^{1}$ CNRS-LETG Caen - Geophen (UMR 6564), Université de Caen Normandie, Caen, France ${ }^{2}$ CRIOBE CNRS-EPHE (USR 3278), 98729 Mooréa, French Polynesia

${ }^{3}$ EASTCO, Université de la Polynésie française, Puna'auia, French Polynesia

*Corresponding author. 


\begin{abstract}
Distant swells produced by high latitude storms are poorly studied despite their significant impact on almost all major ocean basins. This article studies the consequences of extreme southern swells on the islands and atolls of French Polynesia by focusing on lagoon water filling. This phenomenon is a product of great water influx in the lagoon coming from waves breaking on the reef. This analysis is based on archives in Tahiti, and on surveys and interviews conducted in the Makemo Atoll (Tuamotu Archipelago) to identify the impacts of giant swells during August 2011 and July 1996. These swells have strongly affected all the archipelagos of the Western Pacific and have been strongly felt on the entire Pacific coastline of the American continent. In French Polynesia they caused a rise in the lagoons that reached $2.75 \mathrm{~m}$ (above the lowest astronomical tide), causing a major submersion event that strongly impacted the life of the inhabitants by destroying many resources on which they depended. Comparing the swells of 1996 and 2011, this article shows that the filling of the lagoon is largely determined by the duration of the intense wave event and not only by the maximum intensity reached by the swell. Finally, this article raises the question of how this phenomenon is taken into account in town / atoll planning, and the vulnerability of the coastlines of the intertropical zone to distant swells in the context of sea level rise and changes of atmospheric circulation.
\end{abstract}

Keywords: Distant swells, lagoon filling, French Polynesia, sea level rise, atolls, maladaptation. 


\section{INTRODUCTION}

\subsection{Swells from cyclones $\&$ distant swells}

Low coral islands are affected by two types of extremely powerful swells of different origins: cyclonic swells and distant swells. Cyclonic swells are the best studied because they are the most destructive and can lead to catastrophic impacts on humans in both low coral islands and floodplains of large deltas (e.g. ; Karim et al., 2008 ; Fritz, et al., 2009 ; Jonkman, et al., 2009). They affect the coral islands of the three great ocean basins differently. On atolls, the direct impact of these swells is common in the tropical Atlantic (Bahamas, Keys). Hurricane trajectories rarely affect the atolls of the Indian and Pacific Oceans. In these ocean basins, atolls are often very close to the equator and therefore outside the cyclone action zone. In extreme cases, these cyclonic swells can reach a significant height $(\mathrm{Hs})$ of 15 and 20 meters producing total atoll flooding, groundwater salinization (Terry et al., $2009 \&$ 2016), reef destruction, and sometimes the displacement of reef-platform coral boulders of several hundred cubic meters (Canavesio, et al., 2018). But these swells have very limited spatial extent. In fact, the small size of the fetch and the short period of these cyclonic swells limit their propagation. Over 500km from the eye of the cyclone, swells are only of limited danger (e.g., Pedreros, et al., 2010 ; Canavesio, et al., 2014) and their presence is almost imperceptible beyond $2000 \mathrm{~km}$.

This is different from distant swells generated by storms in mid and high latitudes. These storms, which generally flow from west to east in both hemispheres, are much larger than tropical cyclones even though the winds are almost always less intense. The extent of the fetch is much higher than that of tropical cyclones and explains why these swells - whose amplitude can also reach about twenty meters - are endowed with a very high period (15 to 20 seconds). This also explains their capacity to spread over thousands of kilometers while maintaining the ability to significantly impact very large areas (e.g., Cooper et al., 2013 ; Smithers et al., 2014, Wadey et al., 2017).

In the Pacific, swells with the longest periods can "travel" up to ten days in the vastness of the ocean, despite their high speeds ( $48 \mathrm{~km} / \mathrm{h}$ for a swell with a 20 -second period). Indeed, it is common to see powerful swells in California formed about ten days earlier off Antarctica (Reyes, 1996). Before arriving on the shores of the American continent, these swells directly and almost simultaneously impact the low islands of many intertropical Pacific archipelagos. As an example, the swell of December 2008 (from the North), formed south of Kamchatka, would have reached $6 \mathrm{~m}$ in the Marshall Islands, $5 \mathrm{~m}$ in Micronesia and another $4 \mathrm{~m}$ to $4 \mathrm{~m} 50$ on Takuu Island, south of the equator (Hoeke et al., 2013). In all these islands and atolls, the morphogenic (Smithers, et al., 2014) and economic impacts were considerable.

\subsection{Lagoon water filling}


Despite the vastness of the territories concerned, the geomorphological and societal consequences of distant swells are rarely studied. In the Pacific, the December 2008 swell from the North Pacific is by far the best documented (Hoeke et al., 2013 ; Smithers, et al., 2014 ). The swells of the South Pacific, on the other hand, have not been the subject of any specific study with the exception of a brief commentary on the July 1996 swell impacts in the Cook Islands (Solomon, et al., 1999).

This article aims to study the impact of exceptional southern swells on the islands and atolls of French Polynesia. This study proposes to compare the effects of July 1996 and August 2011 swells, which are often considered by the inhabitants as the two most powerful southern swells in the last fifty years in this part of the Pacific. It will therefore be necessary to analyze how the amplitude (Hs), period (P) and duration (D) parameters of these swells combine to determine the global impact of these swells on the coasts and low islands of French Polynesia.

In general, articles (e.g., Pedreros et al., 2010 ; Cooper et al., 2013 ; Hoeke et al., 2013 ; Smithers, et al., 2014) studying swells and their effects highlight the amplitude (Hs) and period (P) to judge the exceptional nature of distant swells. This article assumes that the duration factor (D) of the wave event also has a considerable influence on submersions, especially in the very specific context of atolls. Indeed, when the swell is powerful, waves breaking over the reef generate significant water inflow in the lagoon. This water is carried out directly from the wave breaking zone to the lagoon, or via the small and shallow channels (call "hoas" by Polynesians) which separate the small and low coral islands. This water inflow can produce a significant rise in the level of the lagoon. This phenomenon is the main issue of this study that aims to understand how the wave parameters (Hs, P, D) influence the level reached by the lagoon waters during extreme swells.

Faced with water filling, lagoons seem to have an inertia which could reduce the phenomenon of submersion in the event of extremely intense but short-lived swells. Conversely, swells of comparable intensity, but longer duration, would have a longer amount of time to raise the level of lagoons, significantly amplifying the effects of submersion, especially on shorelines not directly exposed to waves breaking.

\section{MATERIAL \& METHODS}

\subsection{Fieldwork}

\subsubsection{Changes in lagoon water levels in French Polynesia}

Islands and atolls of French Polynesia are interesting for observing lagoon filling thanks to extremely stable lagoon water levels. Indeed, French Polynesia is at an amphidromic point that mitigates the effect of tides. The maximum tidal range (variable according to the islands) is thus limited to a few tens of centimeters (Dumas et al., 2012). Moreover, regional sea level is stable at seasonal scales because the El Niño-Southern Oscillation (ENSO) does not have major effects on sea level in French Polynesia. In the lagoons, this variation is further mitigated by the significant inertia of the lagoons in 
the face of the water filling and emptying phenomenon (through the passes generally) so that the variation of the level of the lagoons under the effect of the tide is sometimes limited to a few centimeters.

In fact, the water filling of lagoons by swells is, by far (Callaghan et al., 2006), the main factor in the variation of water levels in the lagoons, even if the lagoon hydrodynamics of some atolls of the Northern Tuamotu Archipelago, which are protected from large swells from the south, are mainly wind-driven or tidally-driven (Dumas et al., 2012).

To analyze the variation of the level of the lagoons of French Polynesia, a tide gauge network has been set up in recent years in several islands and atolls, notably by the French Hydrographic and Oceanographic Service. Unfortunately, monitoring started too recently to characterize the impact of the swells of 1996 and 2011 in the Tuamotu Archipelago (recording began in 2013 in Makemo and in 2009 in Rangiroa). To carry out this study, it was therefore necessary to investigate the archives (local newspapers) and interview the inhabitants of the atolls to know the maximum water levels reached and the impacts of these two extreme swells in different islands and atolls.

Figure 1: Location map of French Polynesia archipelagos 


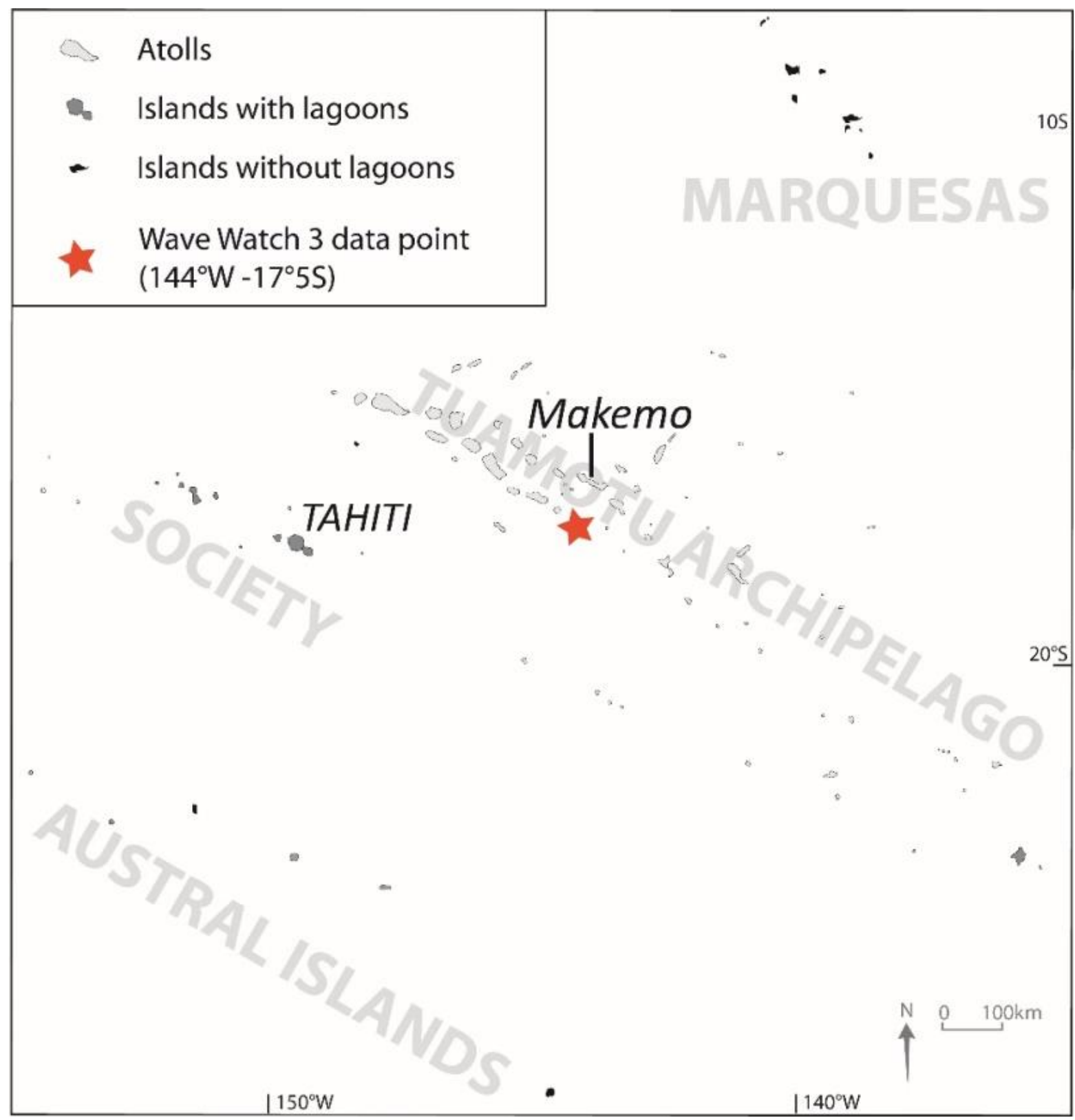

The local daily "Les Nouvelles de Tahiti" (1996) has made it possible to map the main impacts on houses throughout French Polynesia (figure 1). This preparatory work showed that the village of Puheva on the Makemo Atoll (Tuamotu Archipelago) experienced a major submersion during the July 1996 swell.

\subsubsection{Makemo atoll}

Makemo is a large, open $(36 \%)$ and relatively narrow atoll $(68 \mathrm{~km} \mathrm{x} 10 \mathrm{~km})$ located in the center of the Tuamotu Archipelago. Despite its central position, the south coast of Makemo, totally open, is exposed to the southern swells to the extent that no major island is south of Makemo. This south coast is devoid of land and the reef flat at both low and high tide never exceed 1 meter above or below sea level? The population (728 inhabitants) is concentrated in the north near one of the two passes that includes the atoll. 
In February 2015, we conducted a survey and georeferenced interviews with 36 inhabitants of the village of Puheva to draw a precise cartography of the flooded spaces and to know the maximum level reached by the waters in the lagoon of this atoll during the swells of July 1996 and August 2011. The survey dealt with the different forms of submersion and the history of the Makemo atoll in relation to natural hazards. Sometimes photos and videos of these submersions were shown by the inhabitants.

Finally, to precisely know the extent of the phenomenon of lagoon filling, the indications given by the inhabitants of Makemo were reported on a topographic section of the village of Puheva carried out in 2005 by the department of urban planning of French Polynesia. This section, which defines the extent of lagoon filling relative to the reference zero level (lower astronomical tide of the ocean), has a metrical spatial resolution and an altimetric resolution of a few tens of centimeters (Pedreros et al, 2010).

\subsection{Extreme swell events choice}

\subsubsection{Extreme southern swells in French Polynesia}

In French Polynesia distant swells have two distinct sources: the North Pacific and the South West South Pacific. Because of the remoteness with the fetch zone, the swells from the south that occur during the austral winter are still significantly stronger than the North swells. The preferred fetch area is between 6000 and $9000 \mathrm{~km}$ from the Polynesian Tuamotu Archipelago for swells from the North and North-West compared to 3000 to $6000 \mathrm{~km}$ for swells from the South and South-West (figure 2).

To analyze the southern swells, we studied wave models (Wave Watch 3 - 0.5 degrees) derived from the American weather model GFS over the period from January 1, 1979 to January 1, 2015. In the model, the observation point chosen is found in the middle of French Polynesia (figure 1), about a hundred kilometers south of the Makemo atoll in the Tuamotu Archipelago (17.5 ${ }^{\circ} \mathrm{S}$ and $\left.144^{\circ} \mathrm{W}\right)$. It was chosen with care to avoid being concerned by the shadow effect of a nearby island (Andrefouët et al., 2012) for swells from the Southwest, South or Southeast.

Figure 2: Location of the fetch of the swells studied in this article and the December 2008 swell with detailed articles (Hoeke et al., 2013 ; Smithers et al., 2014). 


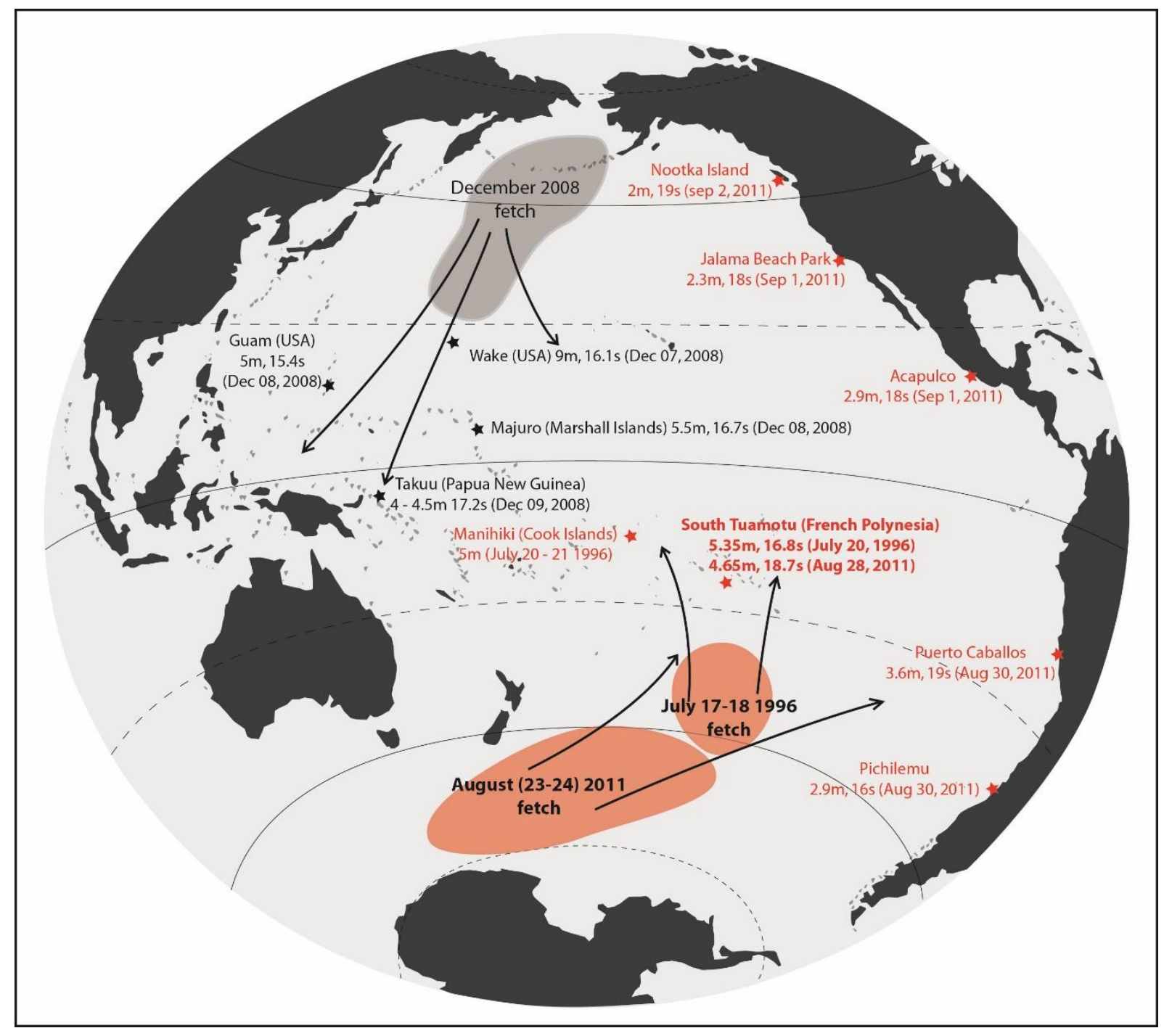

These data show that in the Tuamotu Archipelago, swells in the Southwest, South or Southeast sector regularly reach an amplitude of $3.5 \mathrm{~m}$ to $4 \mathrm{~m}$ with a period of between 15 and 18 seconds. These swells, whose return frequency is approximately annual, have limited impacts as ecosystems and human activities are adapted to these recurring phenomena. The database we consulted also shows that these long swells seldom exceed $4.5 \mathrm{~m}$ (figure 3 ) and that the $5 \mathrm{~m}$ value was only reached once in 36 years, on July 20, 1996.

Figure 3: Chronology of the thirty strongest swells (Hs) between 1979 and 2014 in the Southern Tuamotu Archipelago (17.5 ${ }^{\circ} \mathrm{S}$ and $\left.144^{\circ} \mathrm{W}\right)$. Source: WW3 Global model (0.5 degrees). 


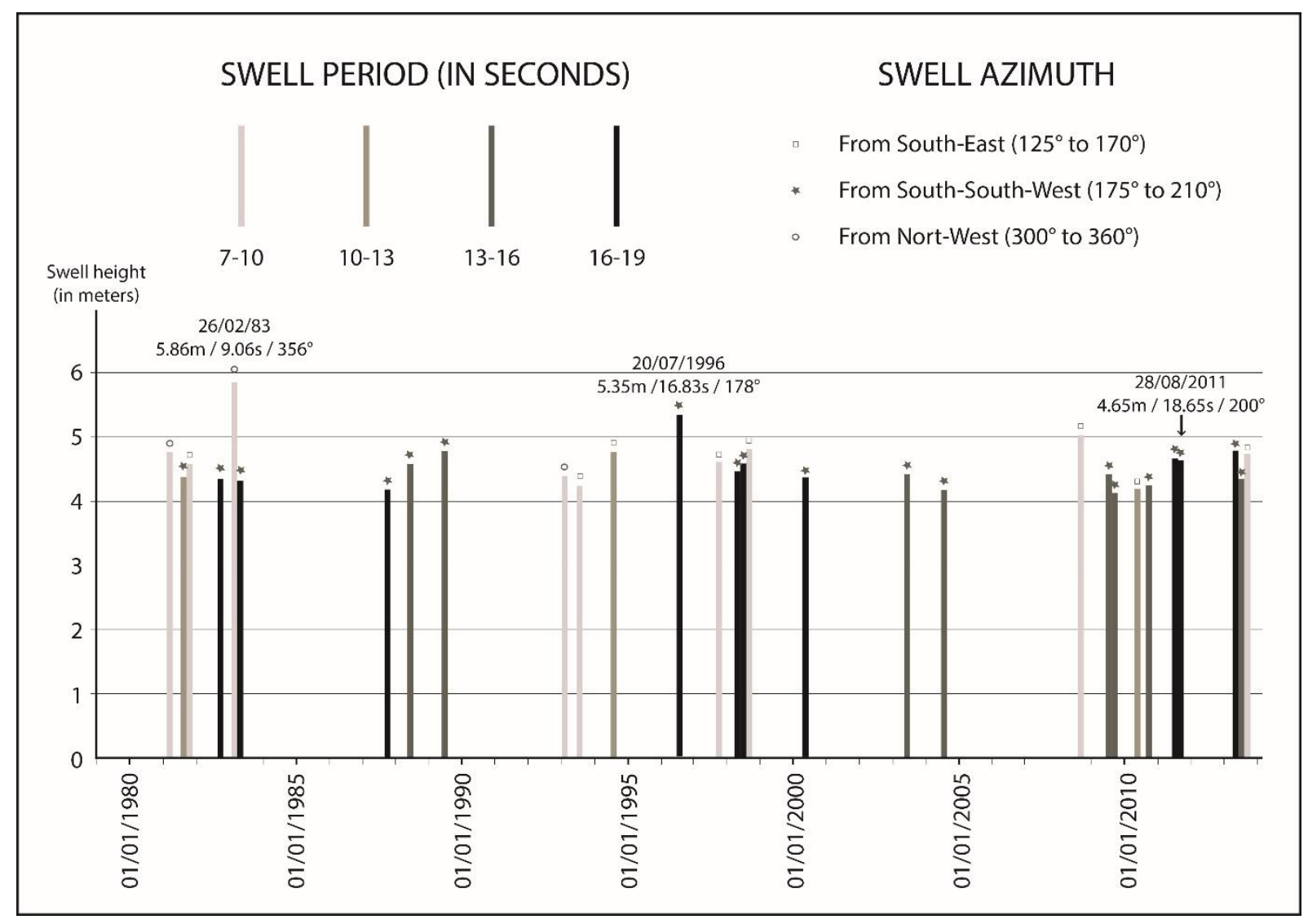

\subsubsection{The exceptional swells of July 1996 and August 2011}

During the period for which we have data from reliable models, the most important swell is the July 1996 swell, the amplitude of which corresponds to a return frequency well above 10 years in Tahiti (Lecacheux et al., 2013), and likely of more than a hundred years. This event is also considered the most intense by the Makemo elders who were met during the field survey conducted in Puheva.

For the oldest people we interviewed (born in the 1920s and 1930s), the swell of 1996 is unanimously considered to be the largest swell of their lives. Another equivalent swell is however sometimes reported "around 1968" by Makemo elders ${ }^{1}$. Finally, in August 2011, another swell characterized by extremely high period values affected the whole of French Polynesia, bringing the authorities to declare a "code red" for "waves and surge" for the first time on the archipelagos of the Austral Islands, Society Islands and Tuamotu Islands. In addition, as part of another study on swell in which the author participated (Harris, et al., 2018), the surfing community of Tahiti (and Teahupoo in particular) was also asked about the history of extreme swells in French Polynesia. The older Tahitian surfers also consider that the swells of 1996 and 2011 are distinguished by their exceptional intensity. In this study, the amplitude (Hs), period (P) and duration (D) parameters of these two extreme

\footnotetext{
${ }^{1}$ This swell could be the North swell of December 2, 1969, which displaced several limestone megaclasts on the north coast of Oahu to Hawaii (Noormets, et al., 2002) and that is sometimes considered the strongest swell of the century by Hawaiian surfers (http://www.hawaiinewsnow.com/story/11625811/the-giant-waves-of-1969will-the-coming-swell-be-even-bigger).
} 
southern swells (July 1996 and August 2011) was studied through the Wave Watch 3 model. First, these parameters were compared with two other remote swells that were scientifically analyzed in the Western Pacific and the Tropical Atlantic in December 2008 (Hoeke et al. al., 2013 ; Smithers, et al., 2014) and in March 2008 (Cooper et al., 2013), respectively. Second, this information is related to the impacts observed on the scale of French Polynesia and on the local scale of Puheva village on the north coast of Makemo Atoll. On the scale of French Polynesia, these impacts are evaluated from the local press archives. At the Makemo scale, we relied on surveys and interviews conducted in February 2015 and on water levels indicated by inhabitants. These testimonies are very consistent and sometimes supported by photos or videos. They are therefore considered reliable with a margin of error of $10 \mathrm{~cm}$.

\section{RESULTS}

\subsection{Characteristics of the July 1996 and August 2011 swells}

\subsubsection{Meteorological context}

Reanalysis of meteorological models (figure 4) shows that the storm that caused the swell of 1996 was relatively modest with a minimum pressure of about $974 \mathrm{hp}$ on July 18 th. However, at the same time, a high-pressure system of 1034hpa only 2000km west of the depression amplified the pressure differential (60hp in total). This difference in pressure is important but not exceptional (table 1).

Figure 4: Meteorological conditions and ground isobar map (in hpa) at the origin of the swells of 1996 (left) and 2011 (right) when the depression reached its lowest pressure. The trajectory of the low pressure center is indicated by red dots. The arrows indicate the main direction of the swell. Data source: NCEP reanalysis surface level, NOAA / ESRL Physical Science Division.



The meteorological situation that produced the August 2011 swell is much more exceptional from this point of view with a total pressure difference of $105 \mathrm{hpa}$ spread over $3200 \mathrm{~km}$. The pressure gradient 
was also slightly higher in 2011. In the center of the storm it reached 35hpa in 800km in 1996 (4.4hpa / 100km) against 80hpa in 1600km in 2011 (5hpa / 100km). In 1996, the pressure gradient generated mean sea-level winds near 60 knots that formed a 14-meter swell in the fetch center (Reyes 1996). In 2011, according to observations from the Jason satellite, average winds reached 65 knots and produced an 18-meter swell in the center of the huge fetch located to the south-east of New Zealand.

The unusual nature of the swell observed in Polynesia in 1996 is therefore not due to the intensity or extent of the winds in the fetch zone but rather to the position and orientation of the main fetch. In 2011, the area with the strongest winds was between 4000 and $5000 \mathrm{~km}$ southwest of Tahiti, whereas it was only $2500 \mathrm{~km}$ south of Tahiti in 1996. Moreover, the main axis of the swell was oriented directly to French Polynesia in 1996 while that of 2011 passed to the South of the Polynesian archipelagos (figure $2 \& 4$ ). The speed of movement of the depressions is also very different. As the 2011 storm moved very quickly, the July 1996 storm was not very mobile, which lengthened the duration of the swell episode.

\subsubsection{6 and 2011 mega-swells oceanographic features}

These different meteorological situations explain the differences observed in Polynesia in terms of orientation, amplitude (Hs), period (P) and duration (D) of these two major swells. In terms of orientation, the swell of 1996 was from south to southeast $\left(178^{\circ}\right)$ while the swell of 2011 had a marked western component $\left(200^{\circ}\right)$, more in line with the usual southern swells. The orientation has a direct impact on the effects of shelter between the islands (Andréfouët et al., 2012). The particular orientation of the swell of 1996 fully exposed the atolls of the extreme west of the Tuamotu Archipelago, such as Tikehau and Rangiroa. These islands normally benefit from the relative shelter created by the Windward Islands when the orientation of the swell is more traditional $\left(190^{\circ}\right.$ to $\left.210^{\circ}\right)$.

Figure 5: Evolution over time of the 5 main distant swells of more than $4.5 \mathrm{~m}$ (Hs) and 16 seconds of period (P) in the Tuamotu Archipelago $\left(17.5^{\circ} \mathrm{S}\right.$ et $\left.144^{\circ} \mathrm{W}\right)$ between January 1, 1979 and March 31, 2015. Wave values are modeled every 3 hours (points on the curves). Source: WW3 Global Model (0.5degrees) and https://swellbeat.com/wave-calculator/ (energy). 


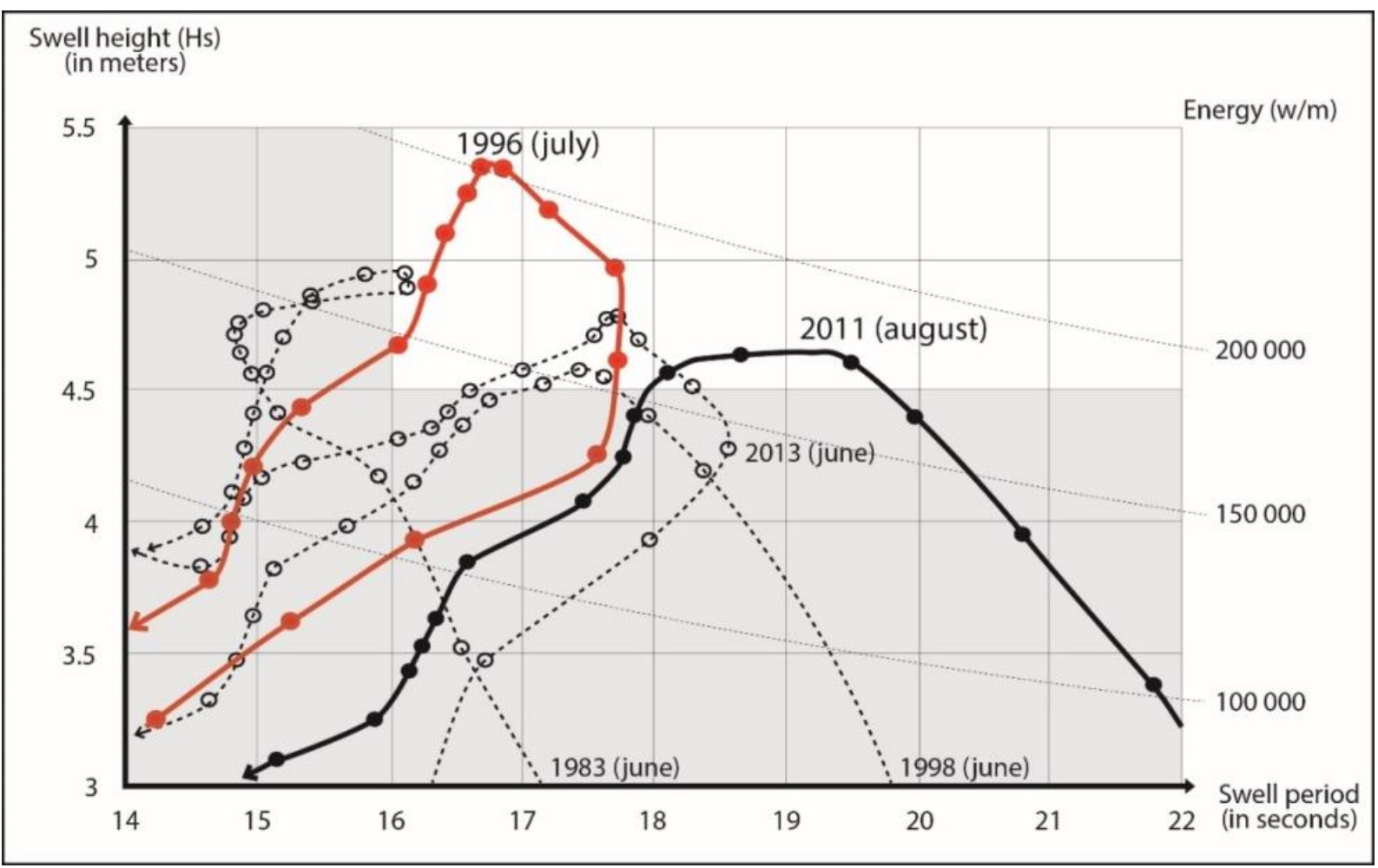

The maximum amplitude reached by a swell at the observation point $\left(17.5^{\circ} \mathrm{S}\right.$ and $\left.144^{\circ} \mathrm{W}\right)$ was significantly greater in $1996(5.35 \mathrm{~m})$ than that observed in $2011(4.65 \mathrm{~m})$. The period of the swell also changed differently over time during these two episodes with a regular and rapid decrease of the period in 2011 whereas the period of the swell amplified initially in 1996 before decreasing slowly (figure 5). Finally, the duration of the strong swell episode was also very different because of the unequal speed of the storm movements. In Polynesia, the swell of 2011 was very short with its amplitude (Hs) only exceeding 4.5m for 9 hours, as compared to the swell of 1996 exceeding this value for 27 hours.

Table 1: Main features of the 1996 and 2011 swells, and swells of 2008 whose impacts have been analyzed in Papua New Guinea and the British Virgin Islands. (Source: Quikscatt and Metop satellites (http://manati.star.nesdis.noaa.gov.php), NOAA http://www.vos.noaa.gov/aug_08.shtml), SwellBeat (https://swellbeat.com/wave-calculator/2 and data provided by the authors (Hoeke et al., 2013 ; Smithers, et al., 2014)).

\begin{tabular}{|c|c|c|c|c|}
\hline Swell event & July 1996 (20-21) & August 2011 (28) & $\begin{array}{c}\text { December 2008 (09) } \\
\text { (Smithers et al, 2014; } \\
\text { Hoeke, et al., 2013) }\end{array}$ & $\begin{array}{c}\text { March 2008 (19-20) } \\
\text { (Cooper et al., } \\
\text { 2013) }\end{array}$ \\
\hline $\begin{array}{c}\text { Location of } \\
\text { monitoring }\end{array}$ & $\begin{array}{c}\text { South Tuamotu } \\
\text { (French Polynesia) } \\
\left(17.5^{\circ} \mathrm{S} ; 216^{\circ} \mathrm{E}\right)\end{array}$ & $\begin{array}{c}\text { South Tuamotu } \\
\text { (French Polynesia) } \\
\left(17^{\circ} .5 \mathrm{~S} ; 216^{\circ} \mathrm{E}\right)\end{array}$ & $\begin{array}{c}\text { Takuu Island } \\
\text { (Papua New Guinea) } \\
\left(4.4^{\circ} \mathrm{S} ; 157^{\circ} \mathrm{E}\right)\end{array}$ & $\begin{array}{c}\text { British Virgin } \\
\text { Islands } \\
\left(18.3^{\circ} \mathrm{N} ; 64.4^{\circ} \mathrm{W}\right)\end{array}$ \\
\hline $\begin{array}{c}\text { Maximum swell } \\
\text { height }\end{array}$ & $5.35 \mathrm{~m}$ & $4.65 \mathrm{~m}$ & $4.18 \mathrm{~m}$ & 4.5 to $5 \mathrm{~m}$ \\
\hline $\begin{array}{c}\text { Period during } \\
\text { maximum swell } \\
\text { height }\end{array}$ & $16.8 \mathrm{~s}$ & $18.7 \mathrm{~s}$ & $17.2 \mathrm{~s}$ & $17 \mathrm{~s}$ \\
\hline Maximum energy & 202372 & 175167 & 126478 & 161424 \\
\hline
\end{tabular}




\begin{tabular}{|c|c|c|c|c|}
\hline (w/m) & & & & (Hs max 4.75 m) \\
\hline $\begin{array}{c}\text { Duration of swell of } \\
\text { more than 4.5m }\end{array}$ & $27 \mathrm{~h}$ & $9 \mathrm{~h}$ & $0 \mathrm{~h}$ & Unknown \\
\hline Swell azimuth & $\begin{array}{c}\text { South } \\
\left(178^{\circ}\right)\end{array}$ & $\begin{array}{c}\text { South-South-West } \\
\left(200^{\circ}\right)\end{array}$ & $\begin{array}{c}\text { North-North-East } \\
\left(0^{\circ} \text { to } 15^{\circ}\right)\end{array}$ & $\begin{array}{c}\text { North } \\
\left(355^{\circ} \text { to } 5^{\circ}\right)\end{array}$ \\
\hline $\begin{array}{c}\text { Lowest pressure of } \\
\text { storm and pressure } \\
\text { gradient }\end{array}$ & $\begin{array}{c}974 \mathrm{hpa} \\
\text { Gradient : } 60 \mathrm{hpa}\end{array}$ & $\begin{array}{c}927 \mathrm{hpa} \\
\text { Gradient }: 105 \mathrm{hpa} \text { (first storm) }\end{array}$ & $\begin{array}{c}990 \mathrm{hpa} \text { (second storm) } \\
\text { Gradient : } 45 \mathrm{~h} \text { pa }\end{array}$ & $\begin{array}{c}965 \mathrm{hpa} \\
\text { Gradient : } 73 \mathrm{hpa}\end{array}$ \\
\hline $\begin{array}{c}\text { Average maximum } \\
\text { wind speed on sea } \\
\text { surface }\end{array}$ & $60 \mathrm{kts}$ & $65 \mathrm{kts}$ & $\begin{array}{c}70 \mathrm{kts} \text { (first storm) } \\
80 \mathrm{kts} \text { (second storm) }\end{array}$ & $70 \mathrm{kts}$ \\
\hline $\begin{array}{c}\text { Highest swell in the } \\
\text { core of fetch area }\end{array}$ & $14 \mathrm{~m}$ & $18 \mathrm{~m}$ & $13 \mathrm{~m}$ (first storm) & $14 \mathrm{~m}$ \\
\hline $\begin{array}{c}\text { Distance from core of } \\
\text { fetch area and the } \\
\text { island }\end{array}$ & 2500 to $3000 \mathrm{~km}$ & 5000 to $6000 \mathrm{~km}$ & $\begin{array}{c}5000 \text { to } 6000 \mathrm{~km} \text { (first } \\
\text { storm) }\end{array}$ & 2000 to $2500 \mathrm{~km}$ \\
\hline
\end{tabular}

When these parameters are compared with the other well-documented distant swells that hit the coastline of small tropical islands (table 1), several elements appear. The swell of August 2011 is particularly distinguished by its period, which far exceeds that of all other documented swells (for the intertropical zone) with nearly two seconds more than other swells when they reached their maximum intensity (period of 19 seconds compared to 17 seconds). The maximum wave energy of 2011 (approximately 175,000 w/ m) was therefore greater than that of swells that hit Takuu Island (about 126,000 w / m) and the British Virgin Islands (about 161,000 w / m) in 2008. Nevertheless, it remains $13 \%$ below the maximum energy reached by the swell of 1996 (about $202000 \mathrm{w} / \mathrm{m}$ ) in French Polynesia.

The swell of July 1996 in French Polynesia is also distinguished by its amplitude and duration. Indeed, its amplitude exceeds the swells of 2011 in Polynesia and 2008 in the British Virgin Islands by half a meter. In addition, the extreme values $(>4.5 \mathrm{~m})$ were recorded during 27 consecutive hours whereas this intensity was reached only during 9 hours in 2011.

\subsection{Impacts in French Polynesia}

\subsubsection{Large-scale coastal inundations}

Distant swells always affect vast territories almost simultaneously. The December 2008 swell surveyed by Hoeke (2013) and Smithers (2014) hit almost all the lower islands of the North Pacific between December 7 and 9 with an amplitude greater than $5 \mathrm{~m}$ on a "front" of over $6000 \mathrm{~km}$ (from Guam to Hawaii). The swells of July 1996 and August 2011 that directly affected Polynesia were also felt over a very large area, although the number of archipelagos affected was smaller. These two swells impacted the archipelagos of the Eastern Pacific (mainly French Polynesia, the Cook Islands and Eastern archipelagos of Kiribati) but also the west coast of the American continent. On July 25, 1996, an alert was launched on the Californian coast (Reyes, 1996) about the great swell that had passed four days earlier though Polynesia. The giant swell of August 2011 that formed in southern 
New Zealand maintained an amplitude of about 2.5m from California (CBSNEWS, 2011) to southern Chile, more than $10000 \mathrm{~km}$ from its origin and on a "front" of more than $10000 \mathrm{~km}$ (figure 2), particularly affecting Central America (Cianciulli, 2011).

Figure 6: Impact of the July 1996 swell on the scale of French Polynesia (source: houses flooded or destroyed (Les Nouvelles de Tahiti, 1996); number of houses (ISPF, 2011))

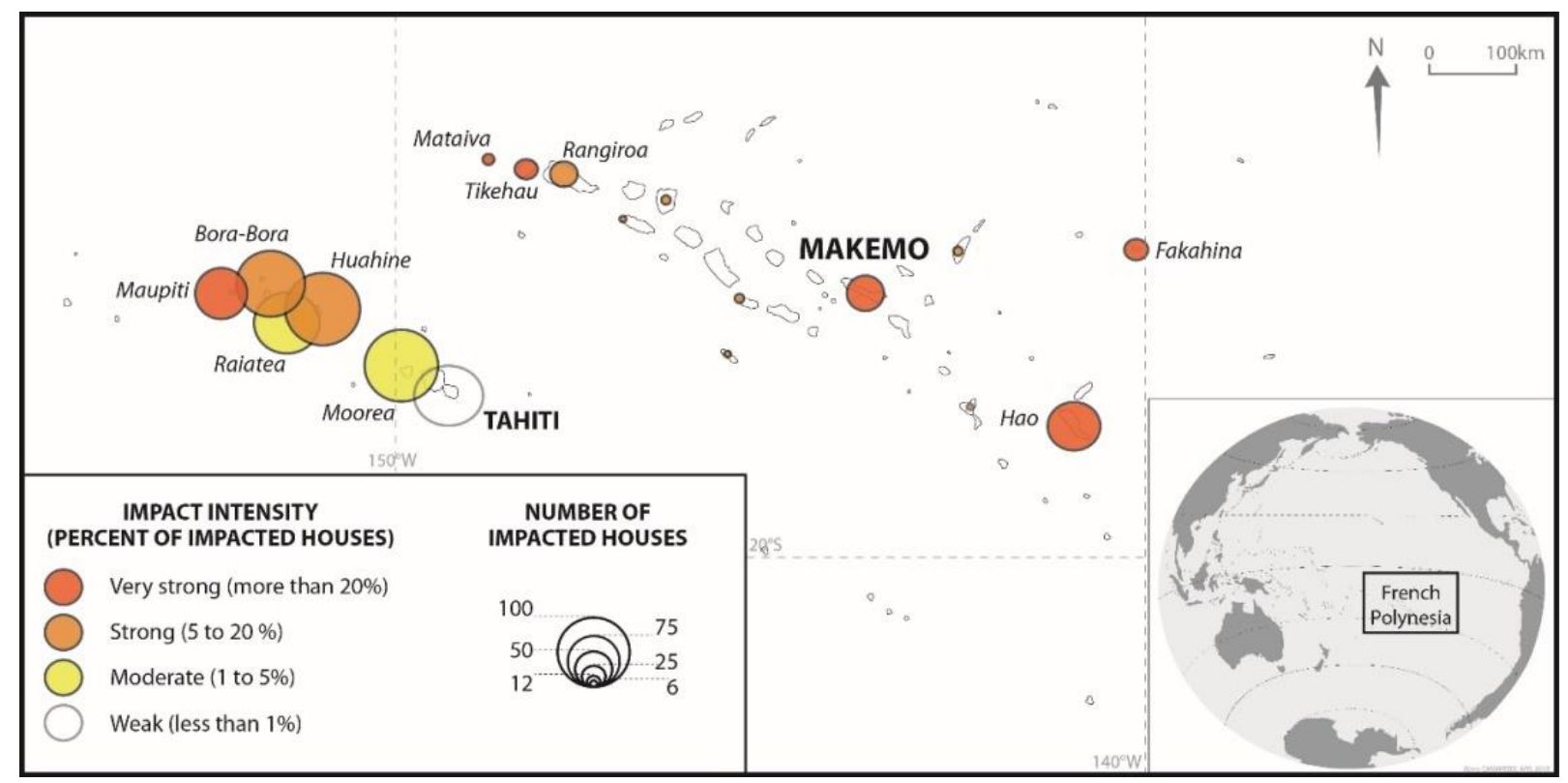

In French Polynesia, closer to the fetch zone, the effects were significant and sometimes spectacular (figure 6). The swell of August 2011 caused localized destruction (flooding of houses, coastal roads, partial destruction of tourist infrastructures) in many islands. According to the local press, which did not necessarily account for the effects of this swell in an exhaustive way, the atolls of Raroia and Hao in the Tuamotu Archipelago were the most affected, concerning houses flooded by the rise of lagoon waters (La Depêche de Tahiti, August 29, 2011). It is impossible to make an accurate assessment of the impact of the swell of 2011 on the scale of Polynesia but it is surely smaller than that of the swell of 1996. In fact, the swell of 2011 will remain in memory as the swell that produced some of the most spectacular surf conditions in history in Teahupoo on the island of Tahiti.

The consequences of the swell of July 1996 are much more important both in terms of infrastructure and from a geomorphological point of view. While we have not kept an accurate record of coral boulder movement during the 2011 swell, the 1996 swell is responsible for large reef-platform boulder displacements on many islands. In Tahiti, several blocks located on the reef barrier of the commune of Punnauia were formally identified as having been put in place by the swell of July 20, 1996. The largest of these blocks is located about forty meters from the wave breaking zone and has a volume of about ten cubic meters, testifying to the energy of this exceptional southern swell.

The impact on human development was also greater in 1996. The local press archives (Les Nouvelles de Tahiti, July 23, 1996) have an island-by-island report card that allows for mapping of the main 
human impacts on the islands on a Polynesia-wide scale. While the exact number of houses flooded or destroyed is not always provided for some Tuamotu atolls, figure 6 shows that islands with very high impacts (more than 20\% flooded or destroyed homes) are spread over a very large area, from the extreme west of French Polynesia (32\% on the high island of Maupiti) to the far East (98\% on the Fakahina atoll). Unlike the swell of 2011, the 1996 swell massively affected the northwestern end of the Tuamotu Archipelago with $25 \%$ of houses flooded or destroyed in Mataiva and Tikehau. The specific analysis of the most affected atolls shows that with the exception of Tikehau, whose village is directly exposed to swell from the South, floods in the other atolls were mainly caused by lagoon filling.

\subsubsection{Lagoon water filling processes in the atoll of Makemo.}

Because of the Makemo atoll's geography, and according to observations, water level of the lagoon is highly correlated with wave stress (figure 7).

Figure 7: Lagoon water level swell dependency (during one month of monitoring in Makemo) 




Even by rising tide it is very common to observe currents coming out through the passes of the atoll when the swell is moderate to strong. As observed in many other atolls, in these conditions, the rise in the lagoon level caused by wave surge exceeds the rise in the level of the ocean caused by the tide. The filling of the lagoon is generally limited to a few tens of centimeters and the acceleration of the flushing current in the pass remains moderate.

When the swell remains of average power ( 1 to $4.5 \mathrm{~m}$ ) the pass is entirely flushed with excess water brought by wave-induced radiation stress, but during exceptional swells such as the 2011 and 1996 ones, water was evacuated by low points of the coral ring (figure 8), including the numerous inter-islet channels along the north coast of the Makemo atoll. According to the population, in these channels, the direction of the flushing current reversed as compared to the usual conditions because, under normal circumstances, they serve to drain water from wave breaking during rare northern swells. In 
1996 , the rise of lagoon water level was so great $(2.75 \mathrm{~m}$ above LAT $( \pm 10 \mathrm{~cm}))$ that it caused severe flooding, including parts of atoll not directly exposed to swells.

Figure 8: Variation of currents in the Makemo atoll according to the swell size. Data derived from local accounts, interviews and inter-islet channel location as seen on Google Earth.

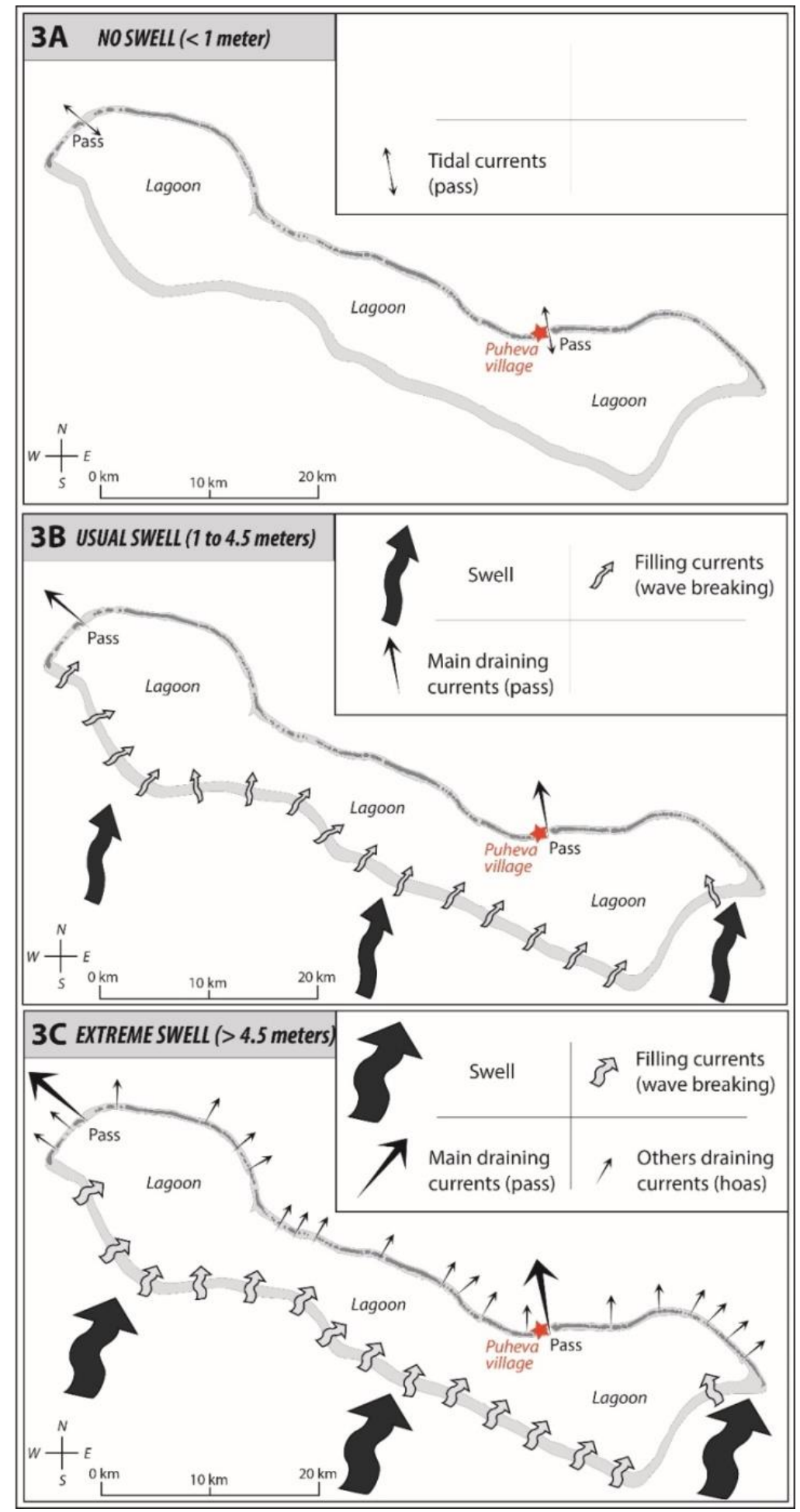

3.2.3. Coastal inundation in Makemo during high-energy lagoon water filling event. 
The major swell episodes - but not exceptional ones - are without consequences for the inhabitants of the Puheva village. In 1996, the rise in the level of the lagoon waters caused the flooding of a large part of the village (38\% of houses were flooded or destroyed) with the exception of the areas where strategic infrastructure (cyclone shelter and health center) was built (figure 9). During this exceptional swell event more than $60 \%$ of the land was flooded by lagoon waters.

Figure 9: 1996 and 2011 flooding on the village of Puheva (north coast of Makemo) produced by swell-driven lagoon filling. 


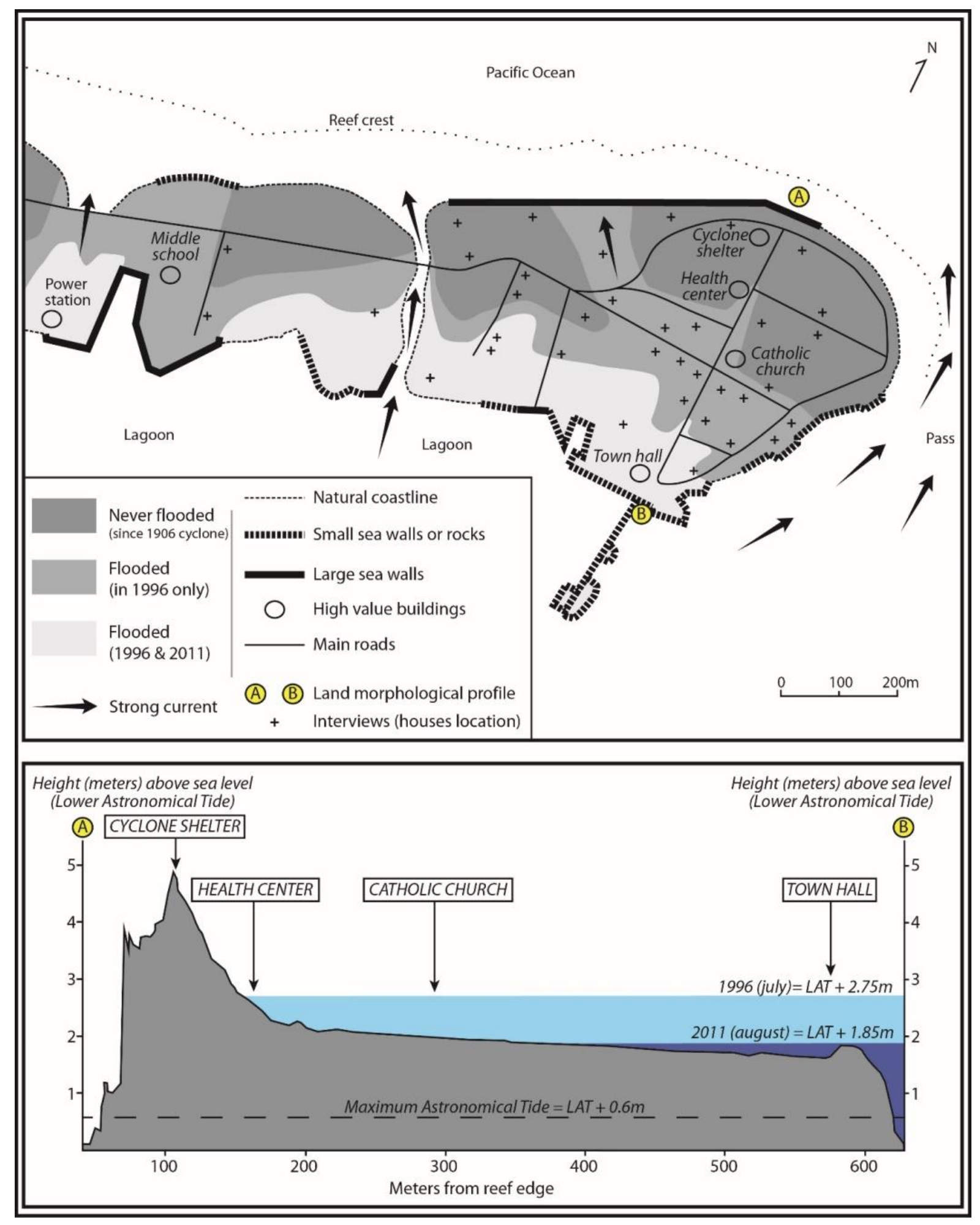

The major wave event of August 2011 had significantly fewer consequences despite the extreme power of this swell whose period reached record levels. In fact, the minimal impact is mainly related to the very short duration of the swell episode in 2011. Unlike the swell of 1996 which was maintained for 27 hours beyond $4.5 \mathrm{~m}$, the swell of 2011 exceeded this value only for 9 hours, leaving no time for the filling phenomenon (figure 10) to reach its equilibrium level (high swell water level). In the end, 
and despite relatively comparable maximum power, the waves of the swell of 2011 caused a filling of "only" 1.85 meters against 2.75 meters in 1996. Thus, if the flooded area in 2011 in Makemo (figure 9) was relatively important, the water levels reached in the village remained relatively modest and the majority of houses (built on slabs of a few tens of centimeters) were spared submersion. The same phenomenon was observed on the coastlines of the Society Islands (Tahiti, Moorea, Bora-Bora, etc.), all of which have a large lagoon capable of delaying and dampening the effect of extreme swells on lagoon filling.

Figure 10: Swell driven lagoon filling and draining, observations at Makemo and conceptual diagram.

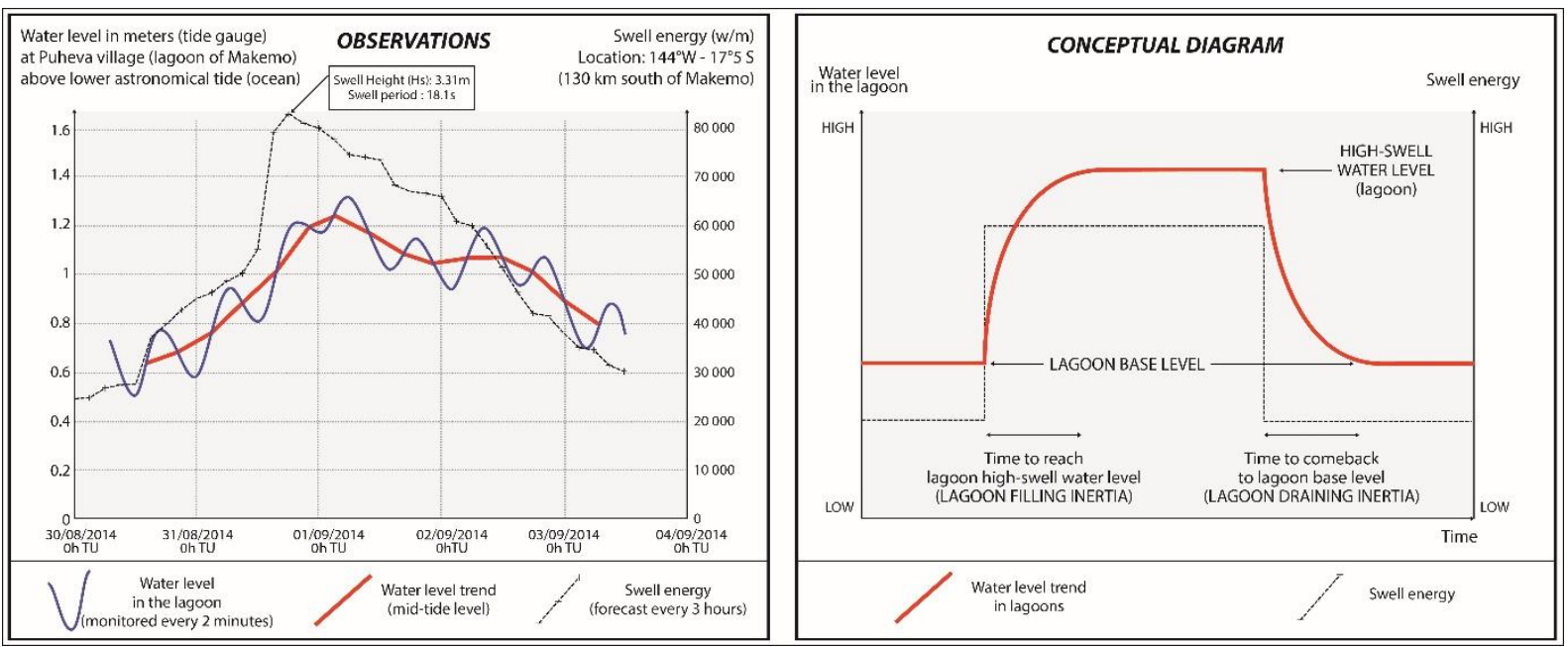

\section{DISCUSSION}

\subsection{Submersions induced by lagoon water filling and their impacts}

These submersions were relatively progressive and calm, amusing the children who have kept a rather happy memory of the traffic of the boats in the streets of the village during 1996 swell event. For adults, the experience was more traumatic.

In 1996, in places (passes, hoas) the evacuation of water from the lagoon in the ocean to the North caused large flushing currents. The population was also surprised to see the direction of flow through the hoa reverse. Worse, the village that had spread out year after year to the point of covering almost the whole islet was literally cut in two distinct parts by the reactivation (but in opposition to the normal current) of an old hoa of which the population had sometimes forgotten about. Indeed, at the bottom of this hoa houses were built after the construction of a major anti-submersion wall. Finally, and this is probably what left the worst memories, the rise in sea level caused the overflowing of all septic tanks whose contents spread throughout the village posing significant health risks and contributing - with salt water - to degrade all the furniture and infrastructure of the flooded area. Many interviewees, however, are aware that the consequences of this exceptional rise in the lagoon level could have been more disastrous if the East or South-East winds - common during this season - had 
been present. The wind is able to generate large chop on the lagoon, whose mechanical effects could have led to the destruction of most homes.

Having occurred in very calm weather (almost non-existent wind), these two floods also had very few visible morphogenic consequences on the north coast of Makemo as the lagoon was free of agitation. Almost all respondents, however, mention important ecological consequences such as the death or weakening of most plants that do not belong to the endogenous vegetation in 1996. Many tree species used in the daily diet did not tolerate the invasion of marine waters into the fresh groundwater lens. This salinization of the fresh groundwater lens that has already been analyzed on other sites (White, et al., 2007 ; Bailey, et al., 2009 ; Terry, et al., 2009 \& 2016) during major submersions has had a very negative impact on the flora of all atolls in the French Polynesia. In Makemo, dozens of bread trees (Artocarpus altilis), banana trees (musa), mango trees (Mangifera indica), papayas (Carica papaya) died in the weeks and months following this flood. The productivity of the coconut grove was also heavily reduced by the temporary decline of coconut trees (Coco nucifera). Finally, throughout the duration of the floods, insects, small mammals and other animals of varying size took refuge -with the inhabitants- in the few areas of the city that remained unflooded.

\subsection{Town and atoll planning}

This study adds to others ( e.g., Cooper et al., 2013 ; Hoeke et al., 2013 ; Smithers, et al., 2014) to testify to the important impacts that distant swells can have on the human activities located on the coastlines of the intertropical zone. This article also shows that on atolls, the impacts affect both coastlines directly exposed to breaking waves and coastline that is not facing the swell. The case study of Makemo has shown that extreme lagoon filling can lead to major submersion, including shorelines that are not directly exposed to the swell.

These observations call for reconsidering the importance of lagoon filling in public policies for managing natural hazards in coastal areas. In Makemo for example, the north coast of the atoll has been subjected to much construction and many of the structures have resulted in partial or total blockage of hoas (airport, road, sea walls etc.). The emptying of the lagoon is slowed down by these numerous obstacles, which results in a higher level of the lagoon than would have been observed if these structures had not been put in place. This phenomenon of maladaptation is not specific to Makemo. Indeed, in the atolls of French Polynesia, the vast majority of the habitats and infrastructure is concentrated on the northern coasts, reducing the capacity of lagoon flushing during exposure to dominant swells coming from South.

Finally, this article shows, through the case of Makemo, that maladaptation towards other climatic risks could be caused by public authorities. Indeed, because of their relatively high frequency, flooding produced by distant swells greatly influences the choice of location of infrastructure for the safety of people in case of submersion. This location is rarely analyzed by experts and is preferably carried out on the highest parts of the atolls, the relative height of which guarantees non-submersion 
during the filling of the lagoon by distant swells. Nevertheless, other studies carried out in the lower islands of French Polynesia (Canavesio, (2014, 2017 and 2018); Duvat, et al., 2017) have shown that these high zones, systematically located on the oceanic side of the islets, are by far most exposed to catastrophic submersions caused by tropical cyclones. In other words, the choice which is often made to place the tropical cyclone shelters on the areas that avoid submersion during episodes of distant swell leads to placing these shelters in zones that are the most dangerous in the event of a tropical cyclone.

\subsection{Geography of low islands' and atolls' exposure to distant swells and lagoon water filling}

The low islands of the tropics are differentially affected by distant swells and lagoon water filling because of the shape of the ocean basins. However, almost all atolls (4 million inhabitants) are exposed to this phenomenon. Despite intense winter low pressure activity in the North Atlantic, the low islands of the Caribbean are affected only marginally as swells are mainly directed towards the east and south-east of the basin (Europe, Morocco, Canaries) and to a lesser extent to the southwest. The larger islands and the Florida Peninsula also protect some of the low islands of the Caribbean Sea and the Keys. The northern (Bush et al., 2009) and eastern (Donn, 1959) islands of the Caribbean are nonetheless more exposed. It has been demonstrated (Cooper et al., 2013) that $4.5 \mathrm{~m}$ long swells have a return frequency of about 20 years on the North Shore of the British Virgin Islands. Bermuda, located closest to the fetch zone, is exposed to swells that are both very intense and very frequent. In the Indian Ocean, the archipelagoes of Comoros (Barruol, et al., 2016) and Seychelles benefit from the "shadow" of Madagascar for the powerful southern swells forming in southern Africa. However, this protection is almost non-existent for the more eastern archipelagos of the Maldives (Harangozo, 1992, Maldive Department of Meteorology, 2007, Wadey et al., 2017), Chagos and Mascarene Islands.

In the Pacific, atolls also experience variable exposure to distant swells. Those located in the most western part of the basin benefit from the shelter formed by Australia and New Zealand against southern swells (figure 2). The central Pacific archipelagos, on the other hand, are very regularly affected by a double source of distant swells (Canavesio, 2017): the North Pacific (Fetch zone between Japan and Hawaii, south of Kamchatka) and the South-West of the South Pacific (South and East of New Zealand). The swells formed in the southern hemisphere are the most frequent and the most powerful during the austral winter (June to September) and vice versa.

\subsection{Climate change and rising sea level}

The analysis of the impacts of 2011 and 1996 swells also shows that the consequences of these swells are as dependent on details pertaining as much to the morphology of each island / atoll (location relative to the other islands, form of the lagoon, etc.), and to the specific characteristics to each swell. 
Our analysis showed that the height and period parameters of these swells were not sufficient to estimate the impacts of distant swells on the atolls and on the shorelines of the low islands with a large lagoon. The significance of duration of the extreme swell event was demonstrated by the Makemo case study comparing the elevation of the water level in the lagoon in 2011 and 1996.

It is questionable how climate change will affect atmospheric circulation and what the consequences in terms of frequency, intensity and duration of extreme distant wave events in the different ocean basins will be. The consequences of global warming on the depressive activity in the different ocean basins are still struggling to be identified with certainty by climatic models (Shaw et al., 2016). In any case, the swell of July 1996 in French Polynesia shows that the agriculture (coconut growing in particular) on which the inhabitants of the small islands of the Pacific depend (Canavesio, 2016) are very vulnerable to the submersions caused by the temporary filling of the lagoon under the effect of the strongest distant swells. Consequently, in the event that climate change provokes an increased frequency of episodes comparable to that observed in 1996, one could question whether the islands, atolls and coastlines being impacted by more frequent (Terry et al., 2016) fresh groundwater lens salinization events would remain habitable. Furthermore, it should be analyzed in the coming decades how the progressive rise in sea level will affect the filling and emptying of lagoons during large swells.

\section{CONCLUSION}

This study focused on distant swells and their consequences on atolls and coastlines of the intertropical zone. The work sought to understand how the duration of extreme swells changes submersion intensity.

By studying the exceptional swell episodes of July 1996 and August 2011 coming from the South Pacific, and by analyzing the submersions they caused in the atolls of French Polynesia, we showed that the filling of the lagoons by wave breaking had several hours of inertia (figure 10). This inertia reduced the water level elevation of the lagoons when swell episodes are short-lived. Conversely, the 1996 swell that was a particularly long-lasting high swell event showed that distant swells can produce a temporary elevation of lagoon water up to $2.75 \mathrm{~m}$ above normal water level, causing flooding on both coastlines directly exposed to breaking waves and islets from the coastline that is not facing the swell.

\section{Acknowledgements}

The authors sincerely thank the CNRS-CRIOBE laboratory and the French Development Agency for helping to finance this research. We also thank Kei Anzai and Ian Bouyoucous for the orthographic corrections made, the anonymous reviewers and the editor for their suggestions. 


\section{References}

Andrefouët, S., Ardhuin, F., Queffeulou, P., Le Gendre, R., 2012. Island shadow effects and the wave climate of the western Tuamotu Archipelago (French Polynesia) inferred from altimetry and numerical model data. Mar Pollut Bull. 65, 415-424.

Bailey, R.T., Jenson, J.W., Olsen, A.E., 2009. Numerical modeling of atoll island hydrogeology. Ground Water. 47-2, 184-196.

Barruol, G., Davy, C., Fontaine, F.R., Schlindwein, V., Sigloch, K., 2016. Monitoring austral and cyclonic swells in the «Iles Eparses» (Mozambique channel) from microseismic noise. Acta Oecologica. 72, 120-128.

Bush, D.M., Neal, W.J., Jackson, C.W., 2009. Summary of Puerto Rico's vulnerability to coastal hazards: Risk, mitigation, and management with examples. Geol S Am S. 460, 149-165.

Callaghan, D.P., Nielsen, P., Cartwright, N., Gourlay, M.R., Badlock, T.E., 2006. Atoll lagoon flushing forced by waves. Coast Eng. 53, 691-704.

Canavesio, R., Pons-Branchu, E., Chancerelle, Y., 2018. Consequence of changes in living coral cover for successful U/Th age-dating of reef-platform carbonate boulders produced by high energy marine inundations. Evidence from the 1903 tropical cyclone in the Tuamotu Archipelago (French Polynesia). Coral Reefs. https://doi.org/10.1007/s00338-018-1732-8

Canavesio, R., 2017. Variabilité des risques de submersion aux Tuamotu. In : Bambridge, T., \& Latouche, J.P. (Eds), Les atolls du Pacifique face au changement climatique. Karthala, Paris, pp 21-49. Canavesio, R., 2016. Dépendance des atolls marginalisés de Polynésie française à la coprah-culture". Cahiers d'Outre Mer. 273, 281-285.

Canavesio, R., 2014. Estimer les houles cycloniques à partir d'observations météorologiques limitées : Exemple de la submersion d'Anaa en 1906 aux Tuamotu (Polynésie française). VertigO. DOI : 10.4000/vertigo. 15375

Canavesio, R., Jeanson, M., Etienne, S., 2014. La gestion du risque cyclonique en Polynésie française et ses limites : exemple du cyclone tropical Oli, février 2010. BAGF. 91 (3), 325-337. DOI : 10.4000/bagf.1644

Cianciulli. M., 2011. Giant southern hemisphere swell lights up entire west coast. Surfline. http://www.surfline.com/surf-news/giant-southern-hemisphere-swell-lights-up-entire-west-coast1_59237

CBSNEWS, 2011. Surf's up ! Monster waves hit California. http://www.cbsnews.com/pictures/surfsup-monster-waves-hit-calif/24/

Cooper, A., Jackson, D., Gore, S., 2013. A groundswell event on the coast of the British Virgin Islands: variability in morphological impact. J Coastal Res. SI65, 696-701.

Donn, W.L., McGuinness, W.T., 1959. Barbados storm swell. J Geophys Res. 64(12), 2341-2349. 
Dumas, F., Le Gendre, R., Thomas, Y., Andrefouët, S., 2012. Tidal flushing and wind driven circulation of Ahe atoll lagoon (Tuamotu Archipelago, French Polynesia) from in situ observations and numerical modelling. Mar Pollut Bull. 65(10-12), 425-440.

Duvat, V., Pillet, V., 2017. Shoreline changes in reef islands of the Central Pacific : Takapoto Atoll, Nortern Tuamotu, French Polynesia. Geomorphology. 282, 96-118.

Fritz, H.M., Blount, C.D., Thwin, S., Thu, M.K., Chan, N., 2009. Cyclone Nargis storm surge in Myanmar. Nature Geoscience. 2, 448-449.

Harangozo, S.A., 1992. Flooding in the Maldives and its implications for the global sea level rise debate. In: Woodworth, P.L., Pugh, D.T., DeRonde, J.G., Warrick, R.G., Hannah, J. (Eds.), Sea Level Changes: Determination and Effects. International Union of Geodesy and Geophysics and the American Geophysical Union, pp. 95-99.

Harris, D., Parravicini, V., Rovere, A., Webester, J., Casella, E., Power, H., Colin, A., Canavesio, R., 2018. Future coastal protection is primarily dépendent on coral reef health, not rising sea level. Sci Adv. 4 (2). DOI: 10.1126/sciadv.aao4350

Hoeke, R.K., McInnes, K.L., Kruger, J., McNaught, R., Hunter, J., Smithers, S., 2013. Widespread inundation of Pacific islands by distant-source wind-waves. Global Environmental Change. 108, 128138.

ISPF, 2011. R6- Logements par catégorie, subdivision et commune aux recensements de 1988 et 1996. Jonkman, S.N., Maaskant, B., Boyd,E., Levitan, M.L., 2009. Loss of Life Caused by the Flooding of New Orleans After Hurricane Katrina: Analysis of the Relationship Between Flood Characteristics and Mortality. Risk Analysis. 29 (5), 676-698.

Karim, M.F., Mimura, N., 2008. Impacts of climate change and sea-level rise on cyclonic storm surge floods in Blangladesh. Global Environnmental Change. 18, 490-500.

La Dépêche de Tahiti, 2011 (August 29). Hao sous l'eau, pp 36-37

Lecacheux, S., Bulteau, T., Pedreros, R., Delvallée, E., Paris, F., 2013. Évaluation probabiliste des houles et des surcotes cycloniques en Polynésie française. Bureau des Ressources géologiques et minières : Projet ARAI 3 : Rapport final, 124p.

Les Nouvelles de Tahiti, 1996 (July 23). Un bilan provisoire plutôt lourd : La houle calmée, on constate un peu partout l'étendue des dégâts, pp 2-3

Noormets, R., Felton, A., Crook, K., 2002. Sedimentology of rocky shorelines : 2 : Shorelines megaclasts on the north shore of Oahu, Hawaï - Origins and history. Sediment Geol. 150 (1-2), 31-45.

Pedreros, R., Krien, Y., Poisson, B., 2010. Programme ARAI 2. Caractérisation de la submersion marine liée aux houles cycloniques en Polynésie française. Rapport BRGM/RP- 58990-FR, 64 p.

Reyes, D., 1996 (July 24). Storm from Tahiti will Bring high surf to southland. Los Angeles Times.

Shaw, T.A., Baldwin, M., Barnes, E.A., Caballero, R., Garfinkel, C.I., Hwang, Y.T., Li, C., O’Gorman, P.A., Rivière, G., Simpson, I.R., Voigt, A., 2016. Storm track processes and the opposing influences of climate change. Nat Geosci. 9, 656-665. 
Smithers, S.G., Hoeke, R.K., 2014. Geomorphological impacts of high-latitude storm waves on lowlatitude reef islands - Observations of the december 2008 event on Nukutoa, Takuu, Papua New Ginea. Geomorphology. 222, 106-121.

Solomon, S. M., Forbes, D. L., 1999. Coastal hazards and associated management issues on South Pacific Islands. Ocean Coast Manage. 42, 523-554.

Terry, J.P., Falkland, A.C., 2009. Responses of fresh waterlenses to storm-surge overwash in the Northern Cook Islands. Hydrogeol J. 18 (3), 749-759.

Terry, J. P., Chui, M.T.F.., 2016. Coastal hazards and groudwtare slinization on low coral islands. Geophysical Research Abstracts, EGU General Assembly, vol 18

Wadey, M., Brown, S., Nicholls, R.J., Haigh, I., 2017. Coastal flooding in the Maldives : an assessment of historic events and their implications. Nat. Haz.10(1), 131-159.

White, I., Falkland, T., Perez, P., Dray, A., Metutera, T., Metai, E., Overmars, M., 2007. Challenge in fresh water management in low coral atolls. J Clean Prod. 15, 1522-1528. 
Highlights

- Swells from high latitudes can produce strong flooding on tropical coastlines

- Distant swells can produce a rise of lagoon levels up to 2.75 meters

- The rise of lagoon water levels is slowed down by lagoon filling inertia

- Longer-lasting swells produce higher lagoon levels 